Original Article

\title{
ANTISICKLING ACTIVITY EVALUATION OF FRACTIONS OBTAINED FROM WHOLE EXTRACTS OF NEWBOULDIA LAEVIS P. BEAUV (BIGNONIACEAE)
}

\author{
AFFO DERMANE ${ }^{a} b^{*}$, KAFUI KPEGBA ${ }^{b}$, KOSSI METOWOGOc, M. KOSSI JOPPAc, A. KODJO AKLIKOKOU
}

aDepartment of Pharmacy, Universite de Lome, Togo, bLaboratory of Organic Chemistry and Natural Substances, Universite de Lome, Togo, cLaboratory of Physiology-Pharmacology, Universite de Lomé, Togo

Email: dermaneaffo@yahoo.fr

Received: 03 Oct 2018 Revised and Accepted: 20 Dec 2018

\section{ABSTRACT}

Objective: This study aims to evaluate the fractions from whole extracts of roots and stem barks of Newbouldia laevis and their effect on sickling.

Methods: Hydroethanolic extracts of stem barks and roots of Newbouldia laevis were fractionated by the technics of cold precipitation in ethanol. The fractions obtained after phytochemical screening were subjected to Emmel test to evaluate their anti-sickling activity. Active fractions were tested for DPPH and AAPH assay (AAPH induced membrane lipoperoxidation and evaluation of reduction of hemolysis).

Results: Two fractions were obtained from each whole extract: supernatant and pellet fractions. Supernatants fractions obtained from whole roots barks extract and stem barks extract at a concentration of $30 \mathrm{mg} / \mathrm{ml}$ reduced sickling up respectively to $7 \%$ and $10 \%$ against $86 \%$ for the control Pellets fractions obtained from the both extracts induced coagulation of SS blood at $30 \mathrm{mg} / \mathrm{ml}$ against $86 \%$ for the control

Conclusion: Supernatants fractions of hydroethanolic whole extract of roots and stem backs of Newbouldia laevis promise as the potential source of active molecules against sickle cell disease.

Keywords: Sickling, Supernatant fraction, Newbouldia laevis, Sickle cell disease, SS blood

(C) 2019 The Authors. Published by Innovare Academic Sciences Pvt Ltd. This is an open access article under the CC BY license (http://creativecommons.org/licenses/by/4.0/) DOI: http://dx.doi.org/10.22159/ijpps.2019v11i2.30112

\section{INTRODUCTION}

Sickle cell disease is a genetic hemoglobinopathy of autosomal recessive inheritance affecting the $\beta$ chain of the protein. It is due to an amino acid permutation which induces a change in the confirmation of the chain (qualitative anomalies) that allows it to polymerize when deoxygenated. According to Aygun and Odame [1] there are Hemoglobin A ( $\mathrm{Hb} \mathrm{A}$ ), natural, Hemoglobin S (Hb S) caused by the $\beta_{6}\left(A_{3}\right)$ mutation where glutamic acid (Glu) is substituted by valine (Val) and Hemoglobin $\mathrm{C}(\mathrm{Hb} C)$ caused by the $\beta_{6}\left(\mathrm{~A}_{3}\right)$ mutation where glutamic acid (Glu) is replaced by lysine (Lys).

While healthy carriers of $\mathrm{Hb} \mathrm{S} / \mathrm{HbA}(\mathrm{Hb} \mathrm{AS}$ ) or $\mathrm{Hb} \mathrm{AC}$ have few clinical manifestations, the impact is important for $\mathrm{HbSS}$ homozygotes. The polymerization of hemoglobin will induce a change in conformation of the red blood cell (passage from a biconcave to a sickle shape), reducing both its life and its functional capacity. The clinical signs that will appear initially are chronic anemia and high susceptibility to infections and then complications may arise due to alteration of the blood circulation inducing cerebrovascular accidents caused by vaso-occlusive crisis, hypoxia coupled with pulmonary infiltration resulting in acute thoracic syndrome, aplastic anemia that can lead to death, stunting and various complications in adulthood [2].

In 1994, the World Health Organization (WHO) estimated that 120 million people $(2.3 \%$ in the world) had the sickle-cell mutation. On the other hand, in Africa, this rate can reach $40 \%$ [3].

Available treatments are limited. The marrow transplantation remains at present the only curative treatment but it is not possible in developing countries where the care consist to prevent complications and relieve pains [4].

Treatment with hydroxyurea to reduce the risk of stroke, acute thoracic syndrome and also reduce inflammatory molecules [5] remains expensive for most patients. Blood transfusion is also proposed with some measures that are difficult to implement in our developing countries [6]. For these reasons, sickle cell patients in sub-Saharan Africa resort to medicinal plants that have proved their effectiveness. Plants have played a significant role in maintaining human health and improving the quality of human life for thousands of years. This resulted in an intense global search for plant extracts and their constituents for health care [7].

In this case, our previous studies and that of Joppa et al. [8] demonstrated an anti-sickling effect of roots and stem barks extract of Newbouldia laevis. The objective of this study was to potentiate the anti-sickling effect of total extracts in the fraction(s) of this extract which led to identifying the bioactive compounds. This study was performed to evaluate the effects of fractions from total extracts on sickling.

\section{MATERIALS AND METHODS}

\section{Materials}

Plant material

Roots and stem barks of Newbouldia laevis were harvested at Tsévié, an area that is situated at $35 \mathrm{~km}$ at the northern part of Lomé in December 2014. The plant had been identified at the Botany Department of the Faculty of Sciences of the University of Lomé where it is registered in the herbarium and kept under the number 233.

\section{Blood samples}

The SS blood samples used was provided by the hematology laboratory of the CHU Campus. The control of hemoglobin status has been proven by the electrophoresis method of hemoglobin. Only the hematologist after consultation determine the samples to be used. These samples are taken from people who had come for hematological consultation at CHU Campus and who had not undergone blood transfusions for $120 \mathrm{~d}$, in EDTA tubes and used fresh. These people (at least 3) should not have been on anti-sickling and antioxidant treatment for $7 \mathrm{~d}$.

\section{Animal material}

Healthy Wistar rats weighing $90 \mathrm{~g}$ to $100 \mathrm{~g}$ were used to a collected blood sample for evaluation of active fractions antioxidant effect 
These rats have been raised under standard conditions at the animal house of the Department of Animal Physiology of the University of Lomé. The animals were housed in plastic cages and kept in a conditioned atmosphere at $25 \pm 3{ }^{\circ} \mathrm{C}$ and humidity $50-55 \%$ with $12 \mathrm{~h}$ light/dark cycles, they were fed ad libitum with standard pellet diet and had free access to drinking water.

University of Lomé in Togo has a branch of National Ethic Committee that approved the experimental protocols using WHO Guidelines for the care and use human blood and laboratory animals (Ref: 003/0215/BC-BPA/FDS-UL).

\section{Chemicals}

Sodium metabisulphite of formula $\mathrm{Na}_{2} \mathrm{~S}_{2} \mathrm{O}_{5}$, a sickling inducer product has been provided in the form of white powder. Plant extract solutions were prepared with $0.9 \%$ of $\mathrm{NaCl}$. Antioxidant tests required 2,2-diphenyl-1-picrylhydrazyl (DPPH) with ascorbic acid as a reference; 2,2'-azobis 2-amidinopropane dihydrochloride (AAPH) with phosphate buffered saline (PBS) as white and ascorbic acid as the reference.

\section{Experimental protocols}

\section{Fractionation (precipitation method in cold ethanol)}

Hydroethanolic (20/80 v/v) extract of Newbouldia laevis stem and roots barks was used to obtain two fractions of each: pellet and supernatant fractions. To $20 \mathrm{~g}$ of each whole extract was added 200 $\mathrm{ml}$ of $75 / 25(\mathrm{v} / \mathrm{v})$ ethanol-water mixture. The mixture is kept cold at $4{ }^{\circ} \mathrm{C}$ for $24 \mathrm{~h}$ [9]. The centrifugation is then carried out at $1500 \mathrm{rpm}$ for $15 \mathrm{~min}$. The supernatant is then collected, the resulting pellet is dissolved by the same volume of solvent (75\% ethanol-water) and cooled again to be treated under the same conditions as above. The two supernatants are mixed and evaporated under vacuum at $45^{\circ} \mathrm{C}$ using rotavapor R-210 as well as the pellet to obtain the supernatant fraction and the pellet fraction.

The yields obtained are respectively 7.03\%; 6.92\% for supernatant fractions of roots and stem barks and $0.23 \%$; $0.50 \%$ for pellet fractions of roots and stem barks. These yields are calculated with respect to the mass of the whole extract used.

\section{Qualitative phytochemical analysis}

\section{Phytochemical screening tests}

The screening tests of the large phytochemical groups were carried out on the solution of the distilled water. Concentrations of stem and roots barks are $10 \mathrm{mg} / \mathrm{ml}$. Qualitative phytochemical analysis was carried out from the staining tests. Thus, tannins, flavonoids, alkaloids are evidenced by Harbone test [10]; saponosides, terpenoids, steroids, cardiac glycosides, and anthracenics heterosids are evidenced by Chabra and Uiso test [11].

\section{Thin layer chromatography (TLC)}

Supernatant and pellet fractions obtained from the whole extract were analyzed by TLC (thin layer chromatography). The plates used as the stationary phase are silica plates $60 \mathrm{~F}_{254}$ (aluminum) from Merck. Throughout the study Petroleum ether/Acetone (80/20,v/v) was used as mobile phases. Vaniline sulfuric acid has been used as a spray.

\section{Quantitative phytochemical analysis}

\section{Total phenols determination}

Total phenolic content of the extract was determined by the Folin Ciocalteu reaction [12]. Briefly, a mixture of each extract of Newbouldia laevis, Folin-Ciocalteu phenol reagent $10 \%$, and sodium carbonate (700 $\mathrm{Mm}$ ) was prepared and allowed to stand at room temperature for 30 min. After that, the mixture was centrifuged and the supernatant was measured at $735 \mathrm{~nm}$. Gallic acid $(100,50,25,0 \mu \mathrm{g} / \mathrm{ml})$ was used as the standard for the calibration curve. The phenolic contents were calibrated using a linear equation based on the calibration curve. The contents of phenolic compounds were expressed as mg gallic acid equivalent (GAE)/g extract.

\section{Total flavonoids content of the extract}

Total flavonoids content was determined according to the aluminum chloride colorimetric method [12]. Each fraction of extract $(2 \mathrm{ml})$ of Newbouldia laevis $(5,25,50,75,100 \mu \mathrm{g} / \mathrm{ml})$ in methanol was mixed with $2 \mathrm{ml}$ of methanol, $2 \mathrm{ml}$ of $10 \%$ aluminum chloride, $2 \mathrm{ml}$ of $1 \mathrm{M}$ sodium acetate. The mixture was at room temperature for $30 \mathrm{~min}$, the reaction mixture absorbance was measured at $440 \mathrm{~nm}$ with a double beam. Rutin ( 5 to $100 \mu \mathrm{g} / \mathrm{ml}$ ) was used as the standard for the calibration curve. The levels of total flavonoids contents were determined in triplicate and the result was expressed as mg rutin equivalent (RE)/g extract.

\section{Study of anti-sickling activity: emmel test}

In a test tube, $50 \mu \mathrm{l}$ of blood and $50 \mu \mathrm{l}$ of sodium metabisulphite (previously prepared at $2 \%$ in $0.9 \%$ sodium chloride solution and 50 $\mu \mathrm{l}$ of each fraction of extract solution are mixed (at a concentration of $30 \mathrm{mg} / \mathrm{ml}$ ). Then the mixture is left on rest for $4 \mathrm{~h}$ [8]. The control consists of the mixture without extract. The preparation is mounted between the core and the coverslip and bound to the microscope. The percentage of sickling is calculated by reporting sickle cell count on the total number of erythrocytes multiplied by one hundred.

\section{Assessment of the antioxidant effect \\ DPPH test}

A DPPH solution was prepared at $100 \mathrm{mmol} / \mathrm{l}$. The preparation was accurate if reading the optical density (DO) at $517 \mathrm{~nm}$ gaves an absorbance of between 1.030-1.035 [13]. Six range points (ranging from 3.125 to $200 \mu \mathrm{g} / \mathrm{ml}$ ) of ascorbic acid diluted in methanol are prepared. The fraction of extract was also prepared at various concentrations in methanol. To $1.5 \mathrm{ml}$ of DPPH was added $0.25 \mathrm{ml}$ of an extract of each concentration or ascorbic acid range points. Point 0 as a white-reactant was a mixture of $1.5 \mathrm{ml}$ of DPPH and $0.25 \mathrm{ml}$ of methanol. The mixture rigorously has been shaken for $10 \mathrm{~min}$ and the absorbance read at $517 \mathrm{~nm}$. For each concentration, 3 replicates were made. The reduction of rose coloration to yellow coloration was formulated by the inhibition rate. The inhibition rate was calculated according to the formula following: Inhibition rate $=100$ (initial absorbance-sample absorbance)/initial absorbance

\section{AAPH test 'ex vivo'}

Blood collected at the retro-orbital sinus level of the Wistar rats in the NFS tubes (5-6 ml/rat) or blood of the $S$ genotype are centrifuged at $1500 \mathrm{rpm}$ for $10 \mathrm{~min}$ and the resulting red blood cell pellet was washed three times with 5 volumes of PBS ( $\mathrm{pH}=7.2)$ each time [14]. During the last rinse, the tubes were centrifuged at $3000 \mathrm{rpm}$ for $10 \mathrm{~min}$. The pellet obtained after this last rinsing was diluted in 4 volumes of PBS. Six range points ranging from 0 to $500 \mu \mathrm{g} / \mathrm{ml}$ of ascorbic acid are prepared. The dissolve fraction (supernatant) of extract in PBS was prepared with concentrations ranging from $100 \mu \mathrm{g} / \mathrm{ml}$ to $1500 \mu \mathrm{g} / \mathrm{ml}$. Tubes filled with $0.5 \mathrm{ml}$ of red cell suspension are prepared. $0.5 \mathrm{ml}$ of each concentration of extract or ascorbic acid range points was added to this suspension. To the mixture was then added $0.5 \mathrm{ml}$ of AAPH and the whole was incubated well for $3 \mathrm{~h}$ at $37^{\circ} \mathrm{C}$. After the incubation, the mixture was centrifuged at $3000 \mathrm{rpm}$ for $5 \mathrm{~min}$. The absorbance of the supernatant was read at $540 \mathrm{~nm}$. The white consisted of $1.5 \mathrm{ml}$ of PBS and the positive control of $1.5 \mathrm{ml}$ of the mixture PBS, AAPH, suspension of red blood cells in the proportion of $1 / 3$ each. The reduction of hemolysis was formulated by the inhibition rate. The inhibition rate was calculated according to the formula following: Inhibition rate $=100$ (initial absorbance of AAPH-sample absorbance)/initial absorbance of AAPH

\section{Statistics analysis}

The results are processed by the Graphpad 6.02 software and averaged \pm SEM (Standard Error Mean). They are said to be significant if their $\mathrm{p}<0.05$

\section{RESULTS}

\section{Qualitative phytochemical data}

\section{Phytochemical screening}

Phytochemical screening carried out on the various fractions (supernatant and pellet) of the hydroethanolic extracts of Newbouldia laevis roots and stem barks revealed the presence of 
polyphenols, saponosides, terpenoids, and steroids. Alkaloids are absent in the different fractions. Flavonoids and tannins are present in the supernatant fractions, but absent in the pellets of roots. Cardiac glycosides are only present in the supernatants (table 1).

Table 1: Major phytochemical groups present in the different fractions of the roots and stem barks of the hydroethanolic extracts of Newbouldia laevis

\begin{tabular}{|c|c|c|c|c|}
\hline Phytochemical groups & Roots barks supernatant & Stem barks supernatant & Roots barks pellet & Stem barks pellet \\
\hline Tannins & + & + & - & + \\
\hline Flavonoids & + & + & - & + \\
\hline Alkaloids & - & - & - & - \\
\hline Saponosides, Terpenoids, Steroids & + & + & + & + \\
\hline Polyphenols & + & + & + & + \\
\hline Cardiac glycosides & + & + & - & - \\
\hline
\end{tabular}

+Present; -Absent

\section{Thin-layer chromatography}

Supernatant fractions of roots and stem barks showed successively violet and blue spot with the front report $\left(\mathrm{R}_{\mathrm{f}}\right)$ respectively 0.49 and 0.26 (fig. 1).

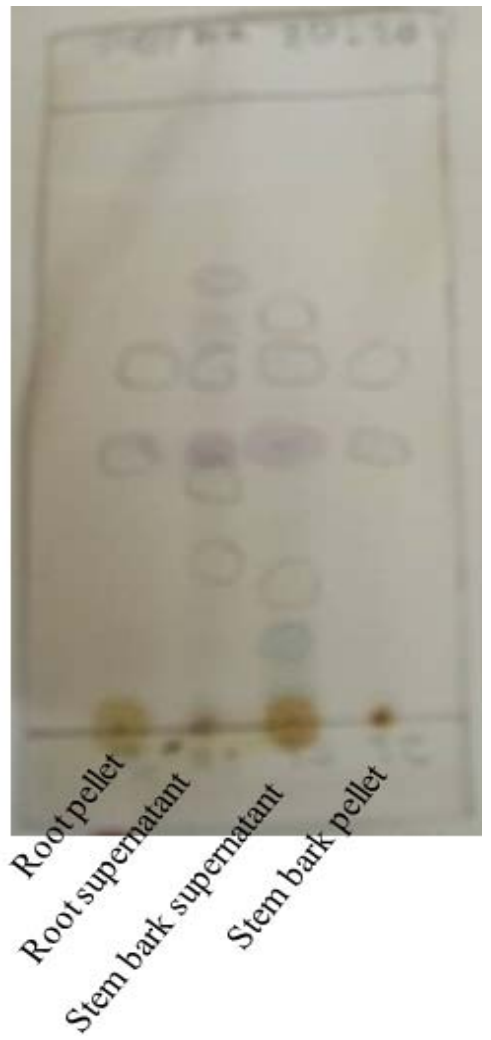

Fig. 1: Thin layer chromatography of different fractions of the whole hydroethanolic extract of roots and stem barks of Newbouldia laevis Reading was realized invisible

\section{Quantitative phytochemical data}

\section{Determination of total phenols and total flavonoids}

Total phenols assay in our active supernatant fractions yielded 34.50 $\mathrm{mg} \mathrm{GAE} / \mathrm{g}$ (milligram gallic acid equivalent per gram) for stem barks versus $36.80 \mathrm{mg} \mathrm{GAE} / \mathrm{g}$ for roots barks. When considering total flavonoids, our results yielded $24.50 \mathrm{mg} \mathrm{RE} / \mathrm{g}$ (milligram rutin equivalent per gram) for stem barks versus $27.50 \mathrm{mg} \mathrm{RE} / \mathrm{g}$ for roots barks (table 2).

\section{Anti-sickling activity}

\section{Supernatants}

The supernatants fractions reduced sickling of SS erythrocytes after $4 \mathrm{~h}$ of incubation. Roots and stem barks supernatants reduced respectively sickling at $7 \%$ and $10 \%$ against $86 \%$ for the control (fig. 2 ).

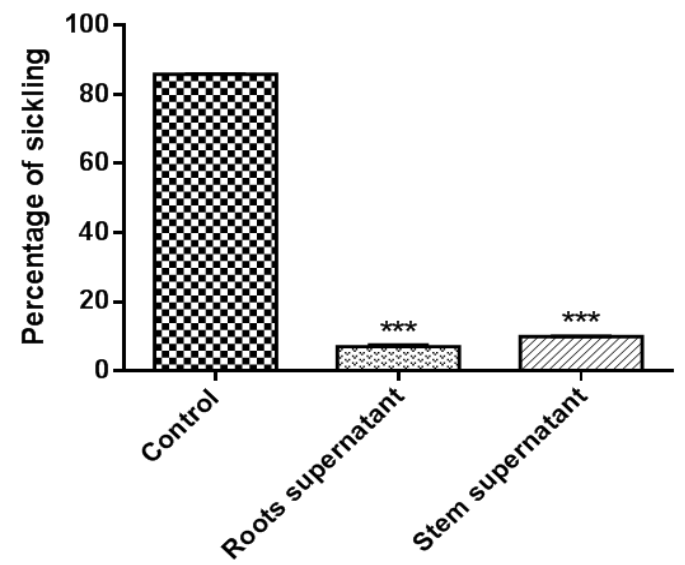

Fig. 2: Percentage of sickling of SS red blood cells in the presence and absence of Newbouldia laevis roots and stem barks supernatants at concentrations of $30 \mathrm{mg} / \mathrm{ml}$, The SS blood is incubated between slide and coverslip in the presence of $2 \%$ sodium metabisulphite and with an equal volume of extract fractions for $4 \mathrm{~h}$. The reduction in sickling of SS red blood cells is significant for both supernatants. Each value represent the mean of sickling percentages $\pm \mathrm{ESM}$ with $\mathbf{n}=3$. $^{* * *}$ p $<0.05$ (Control vs Fraction)

\section{Pellets}

The pellets coagulated the SS blood. Reading was not possible.

\section{DPPH test}

The anti-radical activity of the roots and stem barks supernatant fractions of Newbouldia laevis was evaluated by the DPPH reduction method. Fractions did not show their great ability to trap DPPH compared to ascorbic acid used as a reference drug (table 3 ).

Table 2: Total phenols and flavonoids contained in the different extracts

\begin{tabular}{lll}
\hline Extract & Total phenols (mg GAE/g) & Total flavonoids (mg RE/g) \\
\hline Stem barks supernatant & 34.50 & 24.50 \\
Roots barks supernatant & 36.80 & 27.50 \\
\hline
\end{tabular}


Table 3: IC 50 respectively ascorbic acid and supernatant fractions of Newbouldia laevis roots and stem barks showing their inhibition of DPPH oxidation

\begin{tabular}{llll}
\hline & Ascorbic acid & Roots barks supernatant fraction & Stem barks supernatant fraction \\
\hline $\mathrm{IC}_{50}(\mu \mathrm{g} / \mathrm{ml})$ & 108 & 804 & 746 \\
\hline
\end{tabular}

\section{AAPH test}

The anti-hemolytic effect of the supernatant fractions of the hydroethanolic extracts of the roots and stem barks of Newbouldia laevis was evaluated ex vivo by incubation of the S genotype red blood cells in the presence of a chemical oxidation initiator AAPH. The supernatant fractions inhibited hemolysis in a dose-dependent manner and this activity was compared to ascorbic acid by their IC I0 $_{50}$ (table 4).

Table 4: IC 50 values of ascorbic acid and supernatant fractions of Newbouldia laevis roots and stem barks showing their inhibition of AAPH-induced hemolysis

\begin{tabular}{llll}
\hline & Ascorbic acid & Roots barks supernatant fraction & Stem barks supernatant fraction \\
\hline $\mathrm{IC}_{50}(\mu \mathrm{g} / \mathrm{ml})$ rat & 149 & 917 & 774 \\
$\mathrm{IC}_{50}(\mu \mathrm{g} / \mathrm{ml}) \mathrm{SS}$ blood & 98 & 369 & 490 \\
\hline
\end{tabular}

\section{DISCUSSION}

The result of studies showed that the supernatants reduced sickling to $7 \%$ for roots barks and $10 \%$ for stem barks against $86 \%$ for the control. Our previous work has shown that the whole extracts of roots and stem barks of the same plant reduced sickling to $13 \%$ and $16 \%$ respectively for roots and stem barks against 78\% for the control.

The anti-sickling activity of our extracts could be provided by the presence of polyphenols, particularly flavonoids contained in the extract. The dosage of these polyphenols and flavonoids in the extracts and their fractions confirmed this affirmation. The quantitative evaluation is key parameters in setting the standard for crude drugs [15]. Indeed, the amount of polyphenols, especially the flavonoids found in the supernatant fractions is higher than in the total extracts in our previous study. Now, the antisickling activity of fractions is more pronounced than the anti-sickling effect of whole extract and this effect of the fraction is dose-dependent. This hypothesis has been reported in the literature $[16,17]$.

The anti-sickling effect of stem barks was similar to roots barks. The determination of total phenol compounds had shown that.

TLC investigation delivers an impression about the polarity of chemical constituents of Newbouldia laevis extracts. In a way such that compound displaying high $\mathrm{R}_{\mathrm{f}}$ value in the less polar solvent system have low polarity and with less $\mathrm{R}_{\mathrm{f}}$ value have high polarity. This potent biomolecule can be further used for the development of the different drug in the future [18].

Joppa et al. [8] showed that the hydroethanolic extracts of Newbouldia laevis roots barks had an anti-sickling property with a normalization rate of $90 \%$. Mpiana et al. [19] have shown that the aqueous and ethanolic extracts of Jatropha curcas leaf powder have an anti-sickling property with a normalization rate of $67 \%$ for the ethanolic extract and less than $10 \%$ for the aqueous extract. They also showed that anthocyanins, natural pigments are at the base of the anti-sickling activity of this plant. Sawadogo et al. [20] showed that three plants Uatropha curcas, Khaya senegalensis, and Dichrostachys cinerea) have an anti-sickling effect and linked the presence of polyphenols in the extracts to this effect.

Anthocyanosids composed of several anthocyanins whose in vitro anti-inflammatory properties have been demonstrated by Mpiana $e t$ al. [19] are phenolic compounds. In addition, the reducing compounds could contribute to the reduction of ferric iron $\left(\mathrm{Fe}^{3+}\right)$ from methemoglobin to ferrous iron $\left(\mathrm{Fe}^{2+}\right)$ and thus decrease the $\mathrm{Fe}^{3+} / \mathrm{Fe}^{2+}$ ratio.

The anti-sickling activity obtained in our study with the hydroethanolic extracts of the supernatants of Newbouldia laevis roots and stem barks could be related to the presence of these chemical groups in our extracts.

Another authors have shown that there is a correlation between polyphenols contained in extract and antioxidant capacity [21,22].
Sawadogo et al. [20] showed that anthocyanins have the ability to interact with proteins. Their possible interaction with hemoglobin $S$ could compete with the polymerization of this hemoglobin and thus prevent the polymerization of sickle cells.

It is also likely that the presence of polyphenols would reduce the deformability of erythrocytes in the subject SS. Lemonne et al. [23] demonstrated that sickle cell patients with osteonecrosis had greater erythrocyte deformability than patients without osteonecrosis. Osteonecrosis and vaso-occlusive seizures share common risk factors such as reduced erythrocyte deformability. However, these complications arise as a result of sickle cell crisis.

The antioxidant activity is due to the presence of polyphenols. Indeed, the presence of phenolic compounds in the molecular structure of natural antioxidants helps to increase their antioxidant effect [24].

The roots and stem barks supernatant extract from Newbouldia laevis gave low power antioxidant effect from Wistar rat blood. But it is interesting to note that with the SS blood, the antioxidant effect becomes more important.

The DPPH test showed that the extracts weakly reduced this radical. The $\mathrm{IC}_{50}$ of the roots and stem barks extracts are 804 and 746 respectively. These $\mathrm{IC}_{50}$ are too high relative to the $\mathrm{IC}_{50}$ of ascorbic acid used as a positive control which is 108. Similarly, the AAPH blood test of the Wistar rats showed that the antioxidant effect of the hydroethanolic extracts of Newbouldia laevis is also effective ex vivo. But here too their antioxidant power is weak. $\mathrm{IC}_{50}$ of roots and stem barks supernatants fractions were 917 and 774 respectively. But for SS blood the $\mathrm{IC}_{50}$ of roots and stem barks supernatants fractions were 369 and 490 respectively

Our results with DPPH and AAPH (with the blood of Wistar rats) disagree with those found by Ogunlana OE and Ogunlana 00 [25] who had strong antioxidant power of Newbouldia laevis barks. These differences could be explained by environmental influences, the harvest period and the extraction solvents.

Roots and stem barks pellets fractions from Newbouldia laevis caused coagulation of SS blood. The pellets fractions could contain chemical compounds responsible for this coagulation. This effect may justify the traditional use of Newbouldia laevis in postpartum hemorrhages. The Newbouldia laevis pellets could contain chemicals and/or vitamin $\mathrm{K}$ responsible for this coagulating power. It could also have a procoagulant effect. Other studies will build us on the intrinsic mechanisms.

\section{CONCLUSION}

Newbouldia laevis P. Beauv is a plant that is widely used for both roots and stem barks. This study was conducted to evaluate the antisickling activity of the roots and stem barks fractions of Newbouldia laevis P. Beauv. Our results showed that anti-sickling activity is concentrated in supernatants, fractions that concentrate 
polyphenols. The stem barks supernatant could be used like stem barks. The pellets resulted in coagulation of SS blood. Studies to identify the chemical molecules responsible for this activity should be carried out to enable the establishment of improved traditional drug sources.

\section{AUTHORS CONTRIBUTIONS}

All the author have contributed equally

\section{CONFLICTS OF INTERESTS}

All authors have none to declare

\section{REFERENCES}

1. Aygun B, Odame I. A global perspective on sickle cell disease. Pediatr Blood Cancer 2012;59:386-90.

2. Stuart MJ, Nagel RL. Sickle-cell disease. Lancet 2004;364:134360.

3. Bardakdjian J, Wajcman H. Epidemiologie de la drepanocytose. Rev Prat 2004;54:1531-3.

4. Montalembert $M$, Tshilolo L. Les progrès thérapeutiques dans la prise en charge de la drepanocytose sont-ils applicables en afrique subsaharienne? Med Trop 2007;67:612-6.

5. Penkert RR, Hurwitz JL, Thomas P, Rosch J, Dowdy J, Sun Y, et al. J. S. Inflammatory molecule reduction with hydroxyurea in children with sickle cell anemia. Haematologica 2018;103:50-4.

6. Rees DC, Robinson S, Howard J. How I manage cell transfusions in patients with sickle cell disease. $\mathrm{Br} \mathrm{J}$ Haematol 2018;180:607-17.

7. Archana D, Dixitha M, Santhy KS. Antioxidant and anticlastogenic potential of Piper longum L. Int J Appl Pharm 2015;7:11-4.

8. Joppa KM, Vovor A, Eklu Gadegbeku K, Agbonon A, Aklikokou K, Gbeassor M. Effet de Morinda lucida Benth (Rubiaceae) et de Newbouldia laevis P. Beauv (Bignoniaceae) sur la falciformation. Med Trop 2008;68:251-6.

9. Kadebe ZT, Metowogo K, Bakoma B, Lawson Evi SP, Eklu Gadegbeku K, Aklikokou K, et al. Antidiabetic activity of Plumeria alba linn (Apocynaceae) root extract and fractions in streptozotocin-induced diabetic rats. Trop J Pharm Res 2016;15:87-95.

10. Harbone JB. Phytochemical methods. Chapman and hall eds New York; 1973. p. 354.

11. Chabra SC, Uiso F. A survey of the medicinal plants of Eastern Tanzanian for alkaloids, flavonoids, saponins, and tannins. Fitoterapia 1990;1:307-16.

12. Missebukpo A, Metowogo K, Diallo A, Lawson Evi P, Eklu Gadegbeku K, Aklikokou KA, et al. Antioxidant effects of Ixora coccinea linn in a rat model of ovalbumin-induced asthma. Afr J Pharm Pharmacol 2013;7:2794-800.
13. Metowogo K, Sama MS, Lawson Evi P, Eklu Gadegbeku K, Aklikokou AK, Gbeassor M. Effet anti-ulcereux de l'extrait hydroalcoolique d'écorce de tronc et de racine de Ficus polita vahl (Moraceae). J Rech Sci Univ Lome 2014;16:13-22.

14. Dai F, Miao Q, Zhou B, Yang L, Liu ZL. Protective effects of flavonols and their glycosides against free radical-induced oxidative hemolysis of red blood cells. Life Sci 2005;78:248893.

15. Pradeepa M, Kalidas V, Geetha N. Qualitative and quantitative phytochemical analysis and bactericidal activity of Pelargonium graveolens L'her. Int J Appl Pharm 2016;8:7-11.

16. Kambale JK, Ngbolua KN, Mpiana PT, Mudogo V, Tshibangu DST, Wumba DMR, et al. Evaluation in vitro de lactivite antifalcemiante et effet antioxydant des extraits d'Uapaca heudelotii baill. (Euphorbiaceae). Int J Biol Chem Sci 2013;7:523-34.

17. Mpiana PT, Mudogo V, Tshibangu DS, Kitwa EK, Kanangila AB, Lumbu JB, et al. Antisickling activity of anthocyanins from Bombax pentadrum, Ficus capensis and Ziziphus mucronata: photodegradation effect. J Ethnopharmacol 2008;120:413-8.

18. Rakam GK, Raja S. Standardization and phytochemical screening of Bougainvillea glabra. Int J Curr Pharm Res 2017;9:75-80.

19. Mpiana PT, Mudogo V, Kabangu YF, Tshibangu DST, Ngbolua $\mathrm{KN}$, Atibu EK, et al. Antisickling activity and thermostability of anthocyanins extract from a Congolese plant, Hymenocardia acida Tul. (Hymenocardiaceae). Int J Pharmacol 2009a;5:65-70.

20. Sawadogo Stanislas, Sanou Sagazaga Drissa, Dabire Prosper, Belemtougri Gourounga Raymond, Sawadogo Laya, De Leiris Joel, et al. Activité antifalcémiante d'extraits de trois plantes médicinales du Burkina Faso: Jatropha curcas, Khaya senegalensis et Dichrostachys cinerea. Int J Biol Chem Sci 2017;11:2016-27.

21. Aoret Asseny R, Souza A, Kpahey F, Konate K. Dichrostachys cinerea wight et Arn (Mimosaceae) hydro-alcoholic extract action on the contractility of tracheal smooth muscle isolated from guinea-pig. BMC Complementary Altern Med 2011;11:1-8.

22. Chohan M, Naugton DP, Jones SL, Opara EI. An investigation of the relationship between the antiinflammatory activity, polyphenolic content, and antioxidant activities of cooked and in vitro digested culinary herbs. Oxid Med Cell Longev 2012;8:627-43.

23. Lemonne N, Lamarre $Y$, Romana M, Mukisi Mukaza M, Hardy Dessources MD, Tarer V, et al. Does increase red blood cell deformability raises the risk for osteonecrosis in sickle cell anemia? Blood 2013;121:3054-6.

24. Kahkonen MP, Hopia AI, Vourela HJ, Rauha J, Pihlaja K, Kujala $\mathrm{TH}$, et al. Antioxidant activity plant extracts containing phenolic compounds. J Agric Food Chem 1999;47:3954-62.

25. Ogunlana OE, Ogunlana OO. In vitro assessment of antioxidant activity of Newbouldia laevis. J Med Plant Res 2008;2:176-9. 